\title{
Chateau Margaux for Seat 2A
}

\author{
Ian Yeoman ${ }^{1}$
}

(C) Springer Nature Limited 2018

The recent headline in the Wall Street Journal (Wall and Parasie 2018) Chateau Margaux for Seat 2A: Emirates Rewrites Rules for Airline embodies the importance of this special issue on luxury and premium pricing. The majority of research published in the last 17 years of the Journal of Revenue and Pricing Management have focused on budget carriers, network pricing, capacity algorithms, ancillary pricing or simulations. At the heart of Revenue Management is Belobaba's (1987) EMSR and other algorithms. Research published in this journal about Business Class and First Class is underwhelmed or non-existent, hence the need to understand Chateau Margaux for Seat 2A.

According to Wall and Parasie (2018)

In November, Emirates rolled out private suites on its newest Boeing 777 jets-three of the 40-square-foot single-seat cabins fit across the width of the airliner. It has upgraded its fleet of chauffeured cars that whisk upmarket fliers to and from the airport, replacing Volvos with BMWs equipped with Wi-Fi hot spots. It spent $\$ 6.7$ million building a lavish lounge at Boston's Logan airport, part of a global makeover that included upgrades for lounges in Singapore and Bangkok.

Last year, Emirates spent \$56 million on its collection of fine French wines alone. It has splashed out $\$ 780$ million on the stuff since 2006 and owns its own wine cellars in France. On a recent flight, cabin crew poured a $\$ 566$ bottle of 1998 Chateau Margaux for its first-class passengers. On some routes, the airline

Ian Yeoman

ian.yeoman@vuw.ac.nz

1 Victoria University of Wellington, Wellington, New Zealand regularly offers the exclusive Hennessy Paradis Imperial cognac, which retails for more than $\$ 1,000$ a bottle. Emirates surprised its first- and business-class passengers on a Dubai-Paris flight in April with an on board wine-tasting master class led by a top vintner.

"I want it to feel like you are walking into a RitzCarlton," says long time President Tim Clark, who helped start the Dubai-owned carrier more than 30 years ago.

The airline is betting that the high profit margins of its luxury tickets will allow it to avoid chasing masses of travelers riding in discounted coach seats. The idea threatens to overturn one of the tenets of how to thrive as a large network carrier.

For most of the airline industry, the strategy focusing on luxury was deemed too expensive and too risky. Carriers have always pushed higher-margin first-class and business seats but without a cohesive understanding. The purpose of this issue is to understand the complexities of premium pricing and luxury through a range of research and practitioner papers across the hospitality and transport industries.

The first paper in this issue by Yeoman and McMahon overviews the future of luxury and premium pricing through four scenarios. Scenario 1, Trading Up to Luxury, discusses how consumers with increased wealth aspire to buy luxury products and experiences. Scenario 2, Prestige Luxury, focuses on the behaviors of the seriously wealthy and examines how the mega-rich influence luxury markets. Scenario 3, Enrichment and Experiential Luxury, illustrates how the concept of luxury has become less about materialism and more about experiences. Scenario 4, Craft and Authentic Luxury, illustrates how the exclusivity of luxury 
is framed by craftsmanship, history, and uniqueness. This paper is based on an examination of the evolution of luxury as a concept and highlights eleven contemporary drivers of change including the democratization of luxury, demanding consumers, and premium pricing. The study allows those involved in luxury industries to understand change and, using the scenarios, to position their products or experiences.

Pohland and Kesgin examine the pricing objectives, strategy determinants, and strategies employed by hotels while taking managerial concerns into account. The study determines managers' key pricing concerns and investigates value-informed pricing strategies and making comparisons. The study indicates similarities and differences in price determination factors in the hotel industry. A significant finding is that upscale hotels place high importance on pricing due to intense competition related to their wider product portfolio in comparison to luxury and mid-scale hotels and tend to rely on competition-based pricing. Although exploratory in nature, the results are valuable and provide compelling. Harkison and colleagues consider what luxury accommodation is by first investigating how luxury accommodation is able to command a premium price, and then identifying the differences in customers' luxury experiences between luxury hotels and luxury lodges. The research findings indicate that properties can command a premium price if their facilities and amenities are of the highest quality, if their staff have high levels of interaction and engagement with guests, and if they present a 'wow factor' while still making their guests feel 'at home.' The luxury accommodation experience is found to be significantly different from standard accommodation experiences. Within the luxury sector, a distinct difference exists in the luxury accommodation experience at lodges versus hotels.

The phenomena of the shared economy have come to the forefront of the hotel industry, changing pricing models and introducing new distribution platforms. Over the past few years, the sharing economy has grown tremendously, driven in part by traveler desires for authentic and unique experiences. Richard and colleagues go beyond the accommodation perspectives to examine how peer to peer providers (P2P) such as Airbnb are supplying supply immersive vacation experiences, acting as a host, guide, concierge, and traveling companion to their guests. The papers explore the ability of $\mathrm{P} 2 \mathrm{P}$ providers to command premium pricing for authentic and immersive $\mathrm{P} 2 \mathrm{P}$ offerings detailing the possibilities, listing drivers of change before positing a scenario that helps envision a future in which $\mathrm{P} 2 \mathrm{P}$ providers seize this opportunity.

Kim and colleagues delve into the phenomena of dual branding. Dual branding is drawing interest in the industry because it offers cost and operational efficiencies. From a luxury perspective, one of their challenges for luxury brands is that they face the risk of being perceived as too accessible thereby losing their exclusive appeal (Yeoman and McMahon-Beattie 2014). Luxury hotel's operators and brand managers may fear potential harmful impacts when paring with a lower-scale brand because luxury customers are generally seeking an exclusive, highly personalized experience. The brand image of higher quality of brand can be diluted when partnering with a lower quality of brand, resulting in lower willingness-to-pay and booking intention. Therefore, luxury hotel managers may have been working with the implicit underlying assumption that they need to provide lower room rates to attract customers than stand-alone luxury hotels attributable to the association with an upper-upscale brand. In addition, upper-upscale hotel managers may implicitly assume that they can charge higher prices than stand-alone upper-upscale hotels due to the partnership with a luxury hotel. This is the dilemma of the study.

What is a fair price for a good or service with added value, hence its luxury? Research in the area of pricing provides adequate insights into how consumers evaluate price before purchase, but it does not explain how consumers evaluate price after purchase. Particularly, previous research on price fairness perceptions focused mainly on price fairness perception of future purchase in situations where the prices of consumer durable and non-durable goods increase. These research studies have broadly identified how price fairness perceptions are formed, how consumers attribute motives for price increase and also identify the outcomes of these price fairness perceptions as purchase intentions. Research in price fairness perceptions has inadvertently ignored the situation of price reduction of past purchases. This study by Abdul empirically examines how consumers perceive their past purchase of innovative consumer durable goods with respect to price, specifically when the consumers are aware that the price of their past purchase has reduced. The study attempts to identify the factors that affect price fairness perceptions of past purchase and its outcomes when there is a reduction in price.

How does Revenue Management work in practice when it comes to luxury hotels? Kimes and Ho show that the application of revenue management (RM) in hotels is different because of the role that price and service delivery play in driving the luxury hotel customer experience drawing upon examples from Accor Hotels. Luxury consumers often take price as a cue for quality and luxury, and given that luxury consumers are less price sensitive, the focus becomes more on providing the experiences that they desire and expect.

Will first class disappear? Nowadays, in the era of commoditization of commercial aviation, airlines' efforts to restore profitability seem to translate more than ever 
with a focus on economy class. Many new aircraft are ordered with high-density configurations, and the existing ones are sometimes reconfigured to offer more economy seats, either by reducing the space occupied by those seats, or by shrinking the capacity of the other cabins. Is there still any first-class demand and how does it differ from the business-class demand? What is luxury in commercial aviation? In this paper, Oancea addresses the role of the first-class cabin in commercial aviation, the challenges of pricing luxury, and whether first class still has a future in the years to come versus private aviation. Thus, the main argument to sustain luxury cabins for the years to come is simply that the human desire for privacy and exclusivity is appreciated across cultures and are considered worth paying for. This is what they are paying a premium for. Hinterhuber and Liozu focus on the topic of premium pricing in B2C and B2B environments. They clarify the differences between luxury and premium pricing and offer relevant examples of both, identifying five trends that impact premium pricing strategies and that can serve as avenues for further research.

Finally, Harkison reviews Professor John Swabrooke's new book The Meaning of Luxury in Tourism, Hospitality, and Events offering an insight to the arguments, core theories, and examples of luxury and its management.

At the end of the special issue on luxury and premium pricing, we hope you now understand the importance of Chateau Margaux for Seat 2A.

Dr. Ian Yeoman

Editor, Journal of Revenue and Pricing Management.

\section{References}

Belobaba, P. 1987. Air travel demand and airline seat inventory management. Cambridge: Massachusetts Institute of Technology.

Wall, R., and N. Parasie. 2018. Chateau Margaux for Seat 2A: Emirates Rewrites Rules for Airlines. Wall Street Journal. https://www.wsj.com/articles/chateau-margaux-for-seat-2a-emi rates-rewrites-rules-for-airlines-1531406181.

Yeoman, I., and U. McMahon-Beattie. 2014. Exclusivity: The future of luxury. Journal of Revenue and Pricing Management 13 (1): $12-22$. 